\title{
SOMATOSTATIN-14 INDUCES DIFFERENT CHANGES IN THE THYMUS OF PERIPUBERTAL AND YOUNG ADULT RATS
}

RAKIN K ANA*, PETROVIĆ-ĐERGOVIĆ M DANICA*, TODOROVIĆ N VERA**, ŽIVKOVIĆ P IRENA*, ĐIKIĆ DRAGOSLAVA**, MILJKOVIĆ BILJANA ${ }^{* \star *}$, JANKOVIĆ ${ }^{* \star}$ and MIĆIĆ V MILEVA**

*Immunology Research Centre "Branislav Janković", Institute of Virology, Vaccines and Sera "Torlak", Belgrade, Serbia; **University of Belgrade, Institute for Medical Research, Belgrade, Serbia;

$* \star \star$ Institute of Veterinary Medicine of Serbia, Belgrade, Serbia

(Received 15th January 2010)

Bearing in mind the role of somatostatin in thymus functions, and changes of somatostatin level and expression of its receptors during postnatal life, the aim of this study was to investigate whether centrally applied SRIH-14 induces different changes in the thymic compartments and thymocyte profile in peripubertal and young adult rats. To this end, 4- and 10-week-old male AO rats were cannulated and treated intracerebroventriculary with three doses of SRIH-14, applied every other day. In peripubertal rats, SRIH-14 decreases thymic relative weight and volume, as well as the volume of thymic compartments, especially of deep cortex, as a result of thymocytes loss by apoptosis. Also, SRIH-14 increases the percentage of immature thymocytes preceding the DPTCR $\alpha \beta^{\text {low }}$ cells (DNTCR $\alpha \beta^{-/ l o w}, D P T C R \alpha \beta^{-}$,

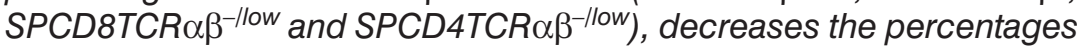
of DPTCR $\alpha \beta^{\text {low }}$ and DPTCR $\alpha \beta^{\text {hi }}$ cells, while the relative proportion of $C D 4^{+} / C D 8^{+} T C R \alpha \beta^{\text {hi }}$ cells remained unaltered. In young adult rats, $S R I H-14$ does not lead to changes in relative thymus weight, although decreases the thymic cortex cellularity and volume. In addition, decreases the percentage of DPTCR $\alpha \beta^{-} /^{\text {hi }}$ cells and increases the percentages of cells within DNTCR $\alpha \beta^{\text {hi }}$ and both SP subpopulations, but much more of the $C D 8^{+} T C R \alpha \beta^{\text {hi }}$ subset. These results suggest that the effects of SRIH-14 on the thymus and thymocytes subpopulations are age-dependent.

Key words: apoptosis, morphometry, rat, somatostatin, thymocyte subpopulations, thymus

\section{INTRODUCTION}

Thymus is a primary lymphoid organ that provides a specialized microenvironment for the development of thymocytes and their maturation into functional $T$ cells. During development thymocytes pass through a series of distinct phases marked by changes in the status of the T cell-receptor (TCR) gene 
rearrangements, positive and negative selection, and in the expression of TCR, co-receptors CD4 and CD8, and other cell surface molecules (Anderson et al., 1994; Starr et al., 2003; Rezzani et al., 2008). Immature thymocytes differentiate through the three-dimensional thymus stromal cells net interacting with different molecules expressed on microenvironmental cell membranes, components of extracellular matrix and soluble factors (Savino and Dardenne, 2000; Savino et al., 2002; Anderson et al., 2007). The soluble factors act on various types of thymic cells, and thus participate in a highly complex network of intercellular communications that governs the functional states and capacities of thymocytes and stromal cells to become/produce immunocompetent, naïve T cells. During postnatal life these soluble factors undergo age-dependent modifications in both synthesis and secretion (Lamberts et al., 1997; Savino and Dardenne, 2000; Gray et al., 2005; Taub and Longo, 2005).

The soluble factors (neurotransmitters, neuropeptides, hormones, cytokines etc.) that drive T cell development originate from, at least, two sources: the thymic stromal cells and the neuroendocrine system. Regardless of its origin, neuropeptides and hormones modulate the maturation of thymocytes over specific receptors expressed on thymic stromal cells and thymocytes (Martens et al., 1996; Dorshkind and Horseman, 2000; Elenkov et al., 2000; Mentlein and Kendall, 2000; Savino and Dardenne, 2000; Savino, 2007).

Numerous studies demonstrated that somatostatin [Somatotropin releaseinhibiting hormone (SRIH)], originally described and isolated from the hypothalamus (Brazeau et al., 1973), influence numerous bodily functions, including the immune response, acting through specific receptors (Bhatena et al., 1981; van Hagen et al., 1994). SRIH family comprises few peptides, but only two of these peptides, SRIH-28 and SRIH-14, are biologically active. Both SRIH-28 and $\mathrm{SRIH}-14$ display overlapping physiological functions and recognize the five cloned somatostatin receptors (sstr) with similar affinities (Krantic, 2000). The presence of SRIH positive cells in the rat thymus and SRIH mRNA in the thymic epithelial cells (TEC) suggests involvement of these cells in the local production of SRIH (Leposavic et al., 1992; Ferone et al., 1999; Silva et al., 2008). SRIH produced within the thymus regulates the expression of somatostatin receptors on the TEC and heterogeneous pool of T lymphoid cell precursors (Ferone et al. 1999; 2002). Three different, selectively expressed somatostatin receptor subtypes, i.e. $s s t_{1}, s s t_{2 a}$, and $s s t_{3}$ receptors are described in the thymus (Ferone et al., 2002, 2004; Petrovic-Djergovic et al., 2007). Their number is subject to significant changes during the aging, and these changes are found to be unrelated to changes in receptor affinity (Ferone et al., 2000).

SRIH released from nerve terminals or locally produced in the thymus, has a direct effect on the inhibition of cell proliferation (van Hagen et al., 1994), on the control of secretory processes in the thymic epithelial cells (Ferone et al., 1999), on cell apoptosis, (Sharma et al., 1996), and on the IGF-1 production (Serri et al., 1992). Furthermore, SRIH inhibits growth hormone (GH) secretion from the pituitary gland. It is less clear, however, whether somatostatin is involved in the local production of $\mathrm{GH}$ from the thymic cells (Maggiano et al., 1994). It is well known that $\mathrm{GH}$ is involved in the thymus growth and function (Savino and 
Dardenne, 2000). Because GH stimulates thymocytes development and/or survival its reduced concentration in puberty can be associated with thymic atrophy (Dominguez-Grepe and Rey-Mendeze, 2003). Principal support of the hypothesis that hormones contributes to thymic atrophy and is based on studies demonstrating an increase of thymic cellularity after $\mathrm{GH}$ administration, in old mice (Murphy et al., 1992). However, results obtained in little (lit) strain of mice suggest that hormonal level changes are not responsible for thymic atrophy (Min et al., 2006).

Considering opposing results obtained for influence of hormones on triggering thymic atrophy, as well as data about changes in sstr expression, but not in affinity, on thymic cells during postnatal life (Ferone et al., 2002; Taub and Longo, 2005) we investigated whether centrally applied SRIH-14 induce different changes in the thymus of peripubertal and young adult rats and if it does whether these changes at investigated ages contribute to thymic atrophy.

\section{MATERIAL AND METHODS}

\section{Experimental animals}

Male rats of Albino Oxford (AO) strain, 4- and 10-weeks old, were used in this study. Animals were housed in our animal colony according to standard conditions, and following current guidelines for the care and use of laboratory animals. The operational procedure of cannulation was performed under total Nembutal anaesthesia (35 mg/kg, intraperitonel, Serve Feinbiochemica, Heidelberg). The anesthetized rats were latched in a stereotaxic apparatus (La Precision Cinematographique, France) and a skin incision was made between the bregma and lambda. The connective tissue over the periost was removed and a cannula impregnated with silicone was inserted into the brain ventricle. Stereotaxic coordinates for cannulations were $2 \mathrm{~mm}$ lateral to the sagittal suture, $2 \mathrm{~mm}$ caudal to the frontal suture and $3.2 \mathrm{~mm}$ ventral to the surface of the cortex. The cannula was affixed to the skull by two metal screws and dental acrylic (Simgal, Galenika, Beograd). Rats were placed in individual cages and allowed to recover for at least one week before being introduced into the experiments.

\section{Protocol}

After recovery, animals from each age group received three doses of SRIH$14(1 \mu \mathrm{g} / 5 \mu \mathrm{L}$ saline; HPLC purity 97\%, Sigma, S-9129), with 48-h intervals between treatments. The control group of peripubertal and young adult rats was treated with $5 \mu \mathrm{L}$ of saline in the same manner as experimental animals. All groups contained 10 animals. The permeance and placement of the cannulas was examined by vital dye tested on the day when the animals were sacrificed. Only animals with a confirmed position in the lateral ventricle were considered for analysis.

The animals were sacrificed $24 \mathrm{~h}$ after the last treatment and their thymuses were removed, weighed and processed for flow cytometric analysis (FCA) or for stereological analyses. 


\section{Preparation of cell suspensions}

Single cell suspensions of freshly isolated thymuses were obtained by grinding the thymus tissue between the frosted glass slides. After washing three times with ice-cold PBS ( $\mathrm{pH} 7.3$; containing $2 \%$ FCS and $0.01 \%$ sodium aside), cells were counted with a hemocytometer and cell viability, determined by Trypane blue dye exclusion, was $>95 \%$.

\section{Flow Cytometry}

Triple fluorescence immunostaining of thymocytes was performed by incubating $1 \pm 0,5 \times 10^{6}$ thymocytes for 30 min at $4^{\circ} \mathrm{C}$, in the dark, in the presence of biotinylated, phycoerytrin-(PE) or fluorescein-isothiocyanate (FITC)conjugated specific antibodies or isotypic and fluorochrome-matched controls at appropriate concentrations. The following mAbs and second layer reagents were used: fluorescein-isothiocyanate (FITC)-conjugated anti-CD4, (clone W3/25, Serotec Oxford, UK); phycoerytrin (PE)-conjugated anti-CD8 (clone MRC OX-8, Serotec, Oxford, UK); biotin-conjugated anti-TCR $\alpha \beta$ (clone R73), mouse IgG1 conjugated to phycoerythrin or fluorescein isothiocyanate (FITS) (isotypic controls, Sigma ImmunoChemicals) and streptavidin-peridinchlorophyll protein (PerCP) (Becton Dickinson).

Cells were analyzed by flow cytometry on FACScan (Becton Dickinson). Forward and scatter light gates were set to exclude dead cells and debris. The analysis was done by FACScan Research Software program (Becton Dickinson).

Apoptosis was analyzed using the Merocyanine $540(1 \mathrm{mg} / \mathrm{mL}$ redistilled; Sigma). All samples were analysed on the flow cytometer using Consort 30 software program.

\section{Morphometry}

The thymuses were weighted and snap frozen in cryostat embedding media (Reichert, Wien, Austria). The serial sections of the thymuses, $5 \mu \mathrm{m}$ thickness, stained with hematoxylin and eosin were analyzed by Olympus $\mathrm{BH} 2$ microscope.

The volume of the thymic cortex, medulla and interlobular connective tissue, as well as numerical density (Nv) of thymocytes, in the outer/deep cortex and medulla were determined on every tenth section of the gland, from each rat, using a multipurpose test system M 42 (Weibel, 1979). For each investigated structure, the size of the final sample was determined, within the confidence interval of $<95 \%$.

\section{Statistical analysis}

The results were expressed as the mean values \pm SD. Values were compared by nonparametric Mann-Whitney U test using the program SPSS 10 for Windows. Differences at $p<0.05$ were accepted as the level of significance. 


\section{RESULTS}

SRIH-14 induced similar changes in peripubertal and adult rats of the body and thymus weight, but not in relative thymus weight

In both age groups of rats treated with SRIH-14, the body weight was significantly reduced compared to corresponding values in control rats of the same age. The reduction of body weight was on the level significance of $p<0.05$ in both treated groups (Fig. 1a). The average thymus weight in both age groups was

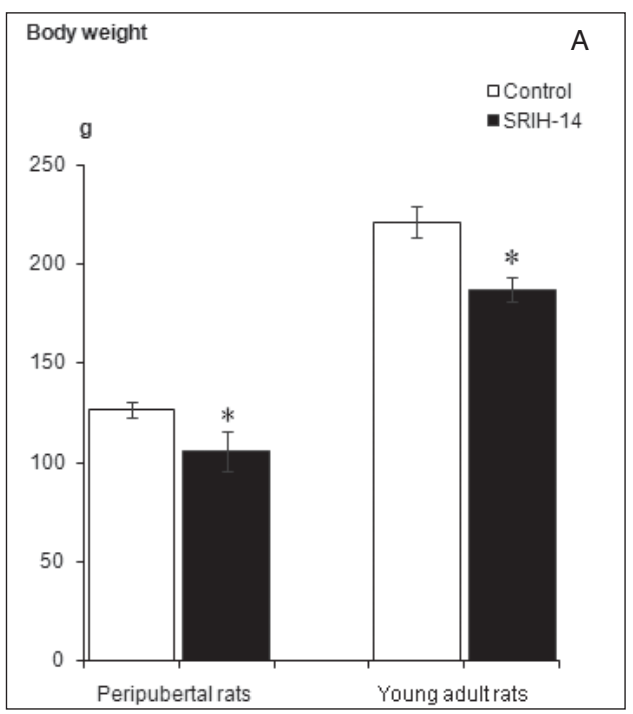
decreased, but in peripubertal rats more $(p<0.01)$ than in young adults $(p<0.05$; Fig. $1 b)$. The relative thymus weight, obtained by calculation from the proportion of thymus and body weight, was significantly reduced in peripubertal rats $(p<0.05)$, while in the young adults was unchanged (Fig. 1c).
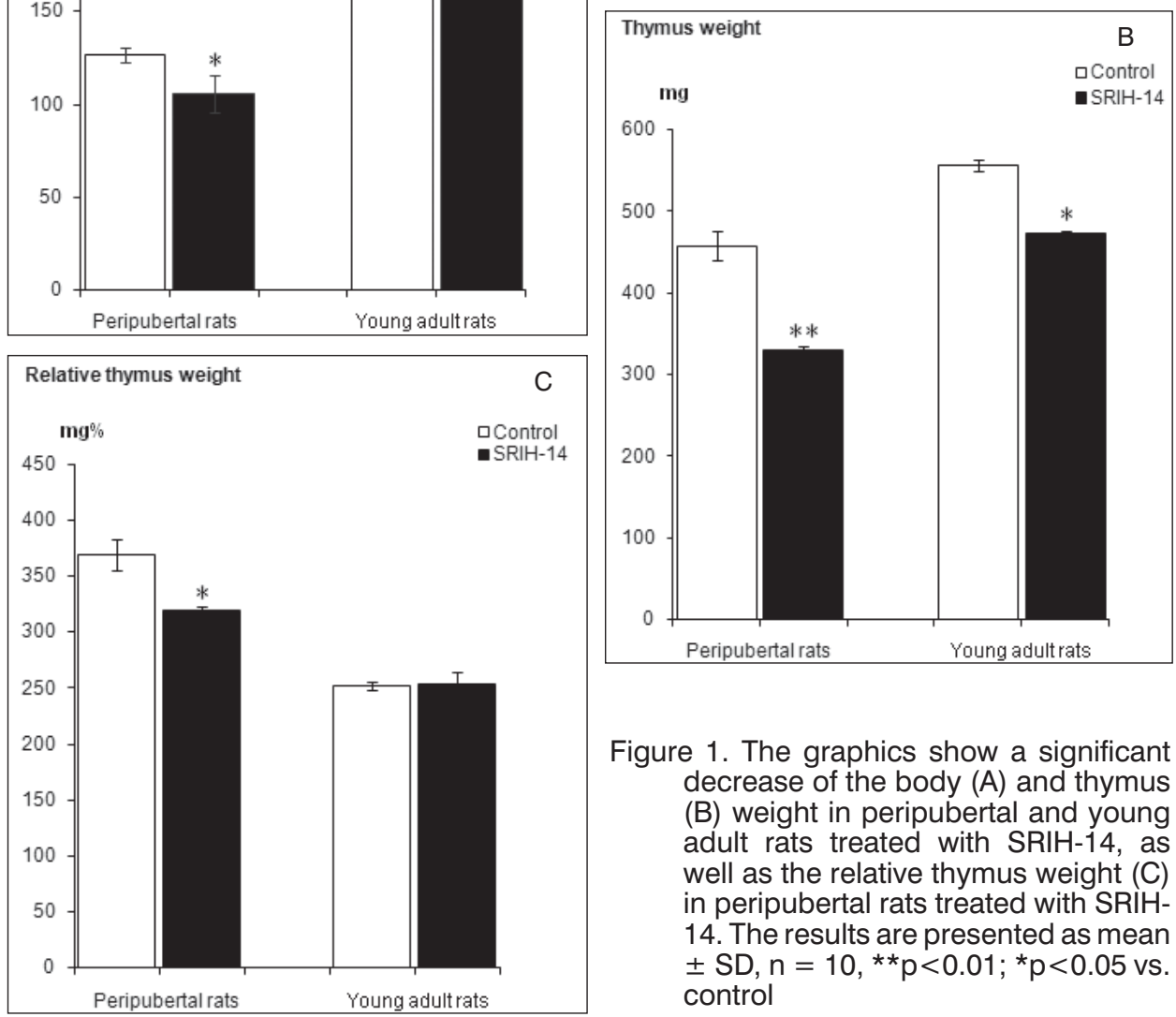

Figure 1. The graphics show a significant decrease of the body $(A)$ and thymus (B) weight in peripubertal and young adult rats treated with $\mathrm{SRIH}-14$, as well as the relative thymus weight $(\mathrm{C})$ in peripubertal rats treated with SRIH14 . The results are presented as mean $\pm \mathrm{SD}, \mathrm{n}=10,{ }^{* *} \mathrm{p}<0.01 ;{ }^{*} \mathrm{p}<0.05$ vs. control 
Variations in thymic cellularity and thymic compartments volume in SRIH-14 treated rats of different ages

Reduction of thymus weight might outcome from the changes of thymus size and/or cellularity. The obtained results showed that SRIH-14 significantly decreased the thymic volume in peripubertal rats, while in the young adults the thymic volume decrease was not significant (Fig 2a). Statistically important decrease of thymocytes total yield was observed in both experimental groups compared to age-matched controls, although the mentioned decrease was larger in peripubertal rats $(p<0.01$ in peripubertal; $p<0.05$ in young adults; Fig. $2 b)$. $\mathrm{SRIH}-14$, in peripubertal and young adult rats, also decreased the absolute numbers of cortical thymocytes compared to the corresponding controls. Considering that one quarter of the cortical thymocytes belongs to the outer and three quarters to the deep cortex, we determined the numerical density of thymocytes in these cortical compartments, in order to explain which part of the cortex participated in alterations of the cortical thymic numbers. The results showed a slightly increased numerical density of thymocytes within the outer cortex and a significantly decreased $(p<0.001)$ cell number within the deeper cortex of peripubertal rats treated with $\mathrm{SRIH}-14$ compared to controls (Fig. 3). This neuropeptide, applied in young adult rats, significantly reduced the mean numerical density of thymocytes within both cortical compartments (Fig. 3).
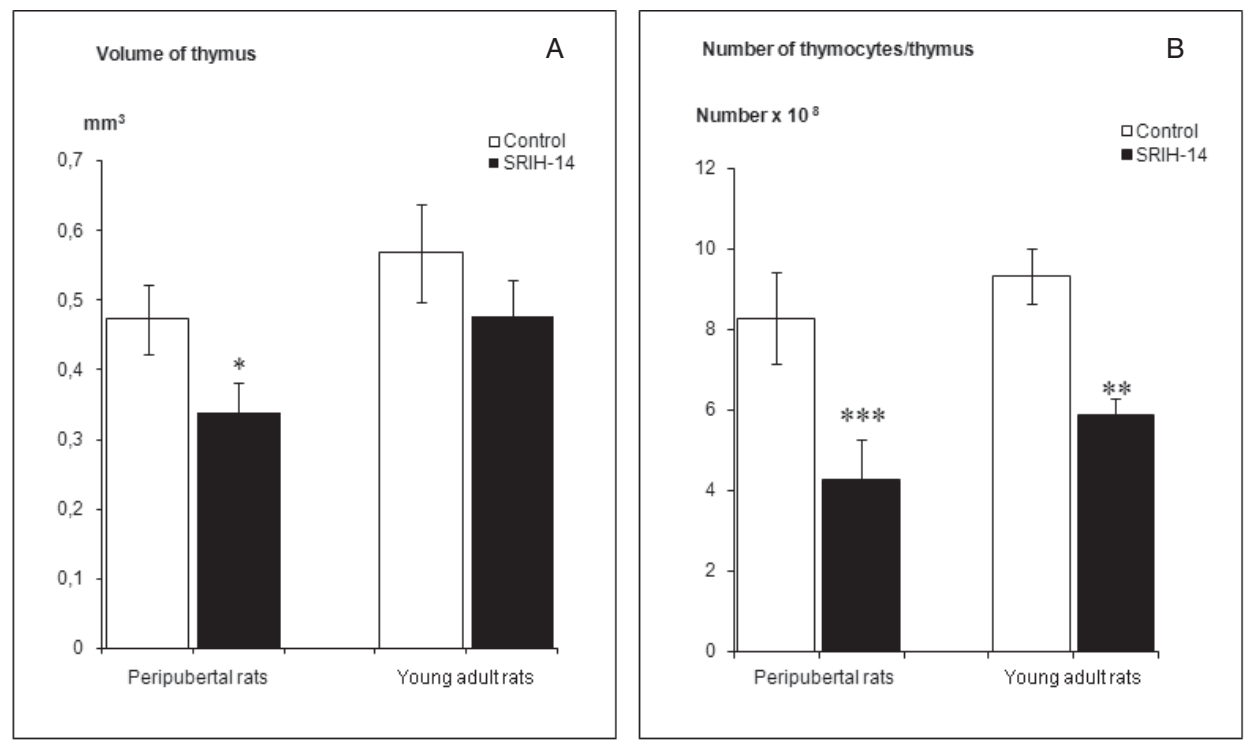

Figure 2. The graphics show significant decrease of the thymic volume $(A)$ in the peripubertal rats treated with SRIH-14. Significant decrease of the total number of thymocytes was detected in peripubertal and young adult rats treated with SRIH-14 (B), as well. The results are presented as mean $\pm S D, n=10 .{ }^{*} p<0.05 ;{ }^{*} p<0.01$; $\star \star \star p<0.001$ vs. control 


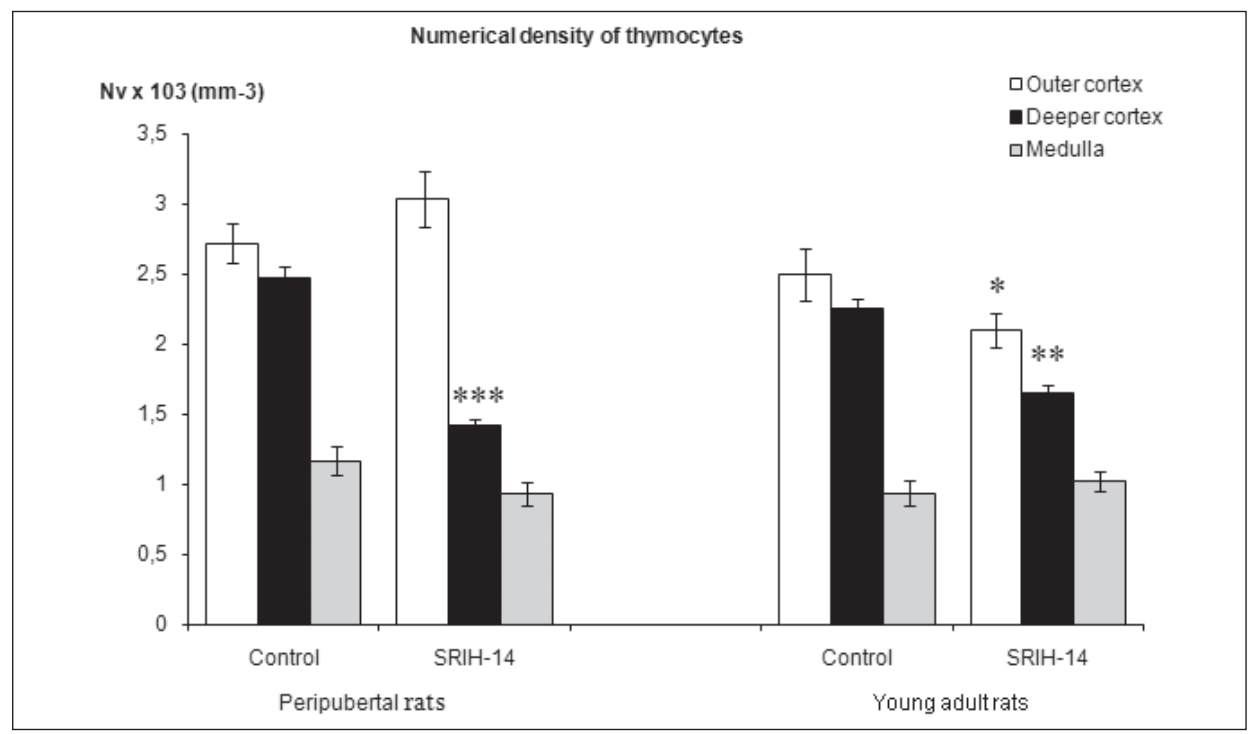

Figure 3. Changes in the numerical density of thymocytes in the various thymic compartments of peripubertal and young adult rats treated with $\mathrm{SRIH}-14$. Values represent mean \pm S.D. $n=10 .{ }^{*} p<0.05 ;{ }^{* \star} p<0.01 ;{ }^{* \star *} p<0.001$ vs. control

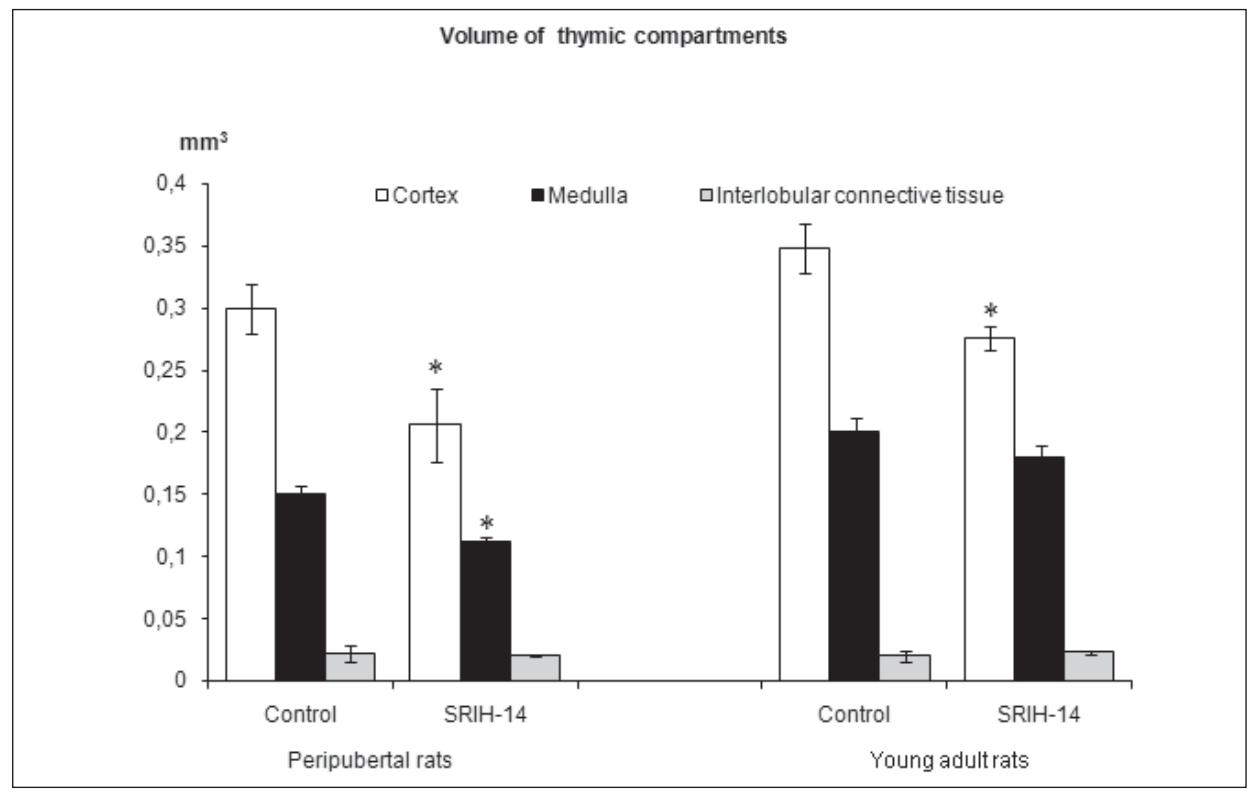

Figure 4. Changes in volume of the thymic compartments in peripubertal and young adult rats treated with $\mathrm{SRIH}-14$. Values represent mean \pm S.D. $n=10$. ${ }^{*} p<0.05$ vs. control 
Bearing in mind the importance of thymus compartments in the process of thymocytes differentiation, we investigated whether application of SRIH-14 evoked morphometric changes in the thymus compartments. The results revealed that SRIH-14 significantly reduced $(p<0.05)$ the volume of the thymic cortex and medulla in peripubertal rats, while in young adults only the thymic cortex volume was significantly affected $(p<0.05$; Fig. 4).

SRIH-14 increased the percentage of apoptotic cells in both experimental groups

To evaluate whether treatment with $\mathrm{SRIH}-14$ changes the percentage of apoptotic cells, Merocyanine 540 staining method was used. The results showed that the percentage of apoptotic cells was increased in both experimental groups compared to age-matched controls, and it was statistically significant $(p<0.05$; Fig. 5).

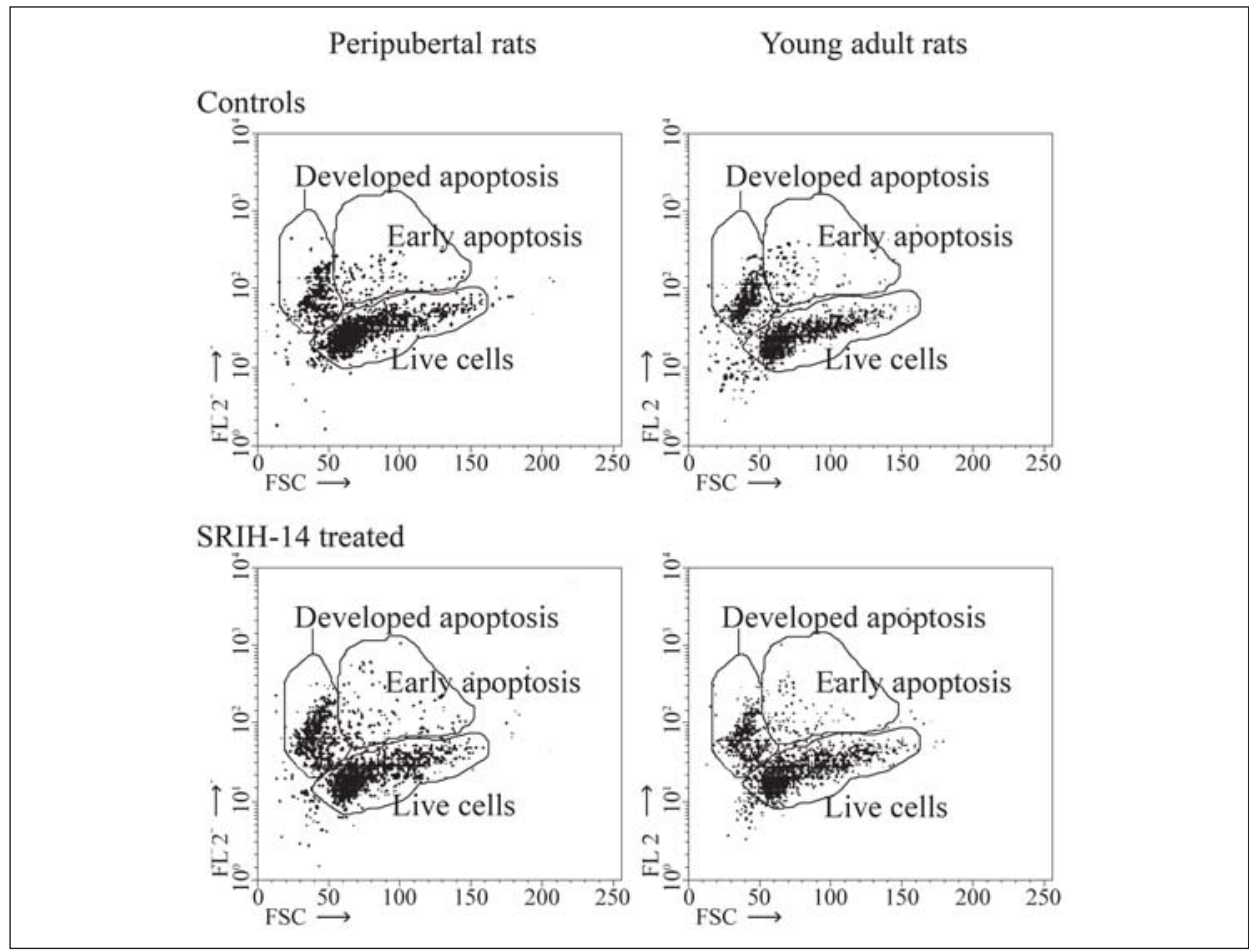

Figure 5. The percentages of apoptotic thymocytes in the thymuses of peripubertal (left) and young adult (right) rats determined by flow cytometry, using dye Merocyanine 540. Representative dot plots display the live cells, cells in early, and developed phases of apoptosis 
Changes in the relative proportion of thymocyte subpopulations in SRIH-14 treated animals are age dependent

The results of this study showed that SRIH-14 treatment alters the relation among thymocyte subpopulations. The mentioned neuropetide increased the percentage of thymocytes within the double negative (DN) subpopulation and both single positive (SP) subpopulations $(p<0.01)$, while reduced the relative proportion of double positive (DP) thymocytes $(p<0.05$; Table 1$)$, in the both experimental groups compared to adequate controls.

Analysis of twelve thymocyte subsets revealed that SRIH-14, in both treated groups, increased the percentage of thymocytes with undetectable and low level of TCR $\alpha \beta$ expression (TCR $\alpha \beta^{- \text {llow }}$ ) within the DN thymocytes subpopulation compared to corresponding control animals. In addition, SRIH also significantly increased the relative proportion of DN TCR $\alpha \beta^{\text {hi }}$ thymocytes, but only in young adult rats (Table 1 ).

Table 1. Percentage of cells within thymocyte subpopulations of control and $\mathrm{SRIH}-14$ treated rats defined by CD4, CD8 and TCR $\alpha \beta$ expression

\begin{tabular}{|c|c|c|c|c|}
\hline \multirow{3}{*}{ Subpopulations } & \multicolumn{4}{|c|}{ Percentage of thymocytes } \\
\hline & \multicolumn{2}{|c|}{ Peripubertal rats } & \multicolumn{2}{|c|}{ Young adult rats } \\
\hline & Control & $\mathrm{SRIH}-14$ & Control & $\mathrm{SRIH}-14$ \\
\hline CD4-CD8- & $2.65 \pm 0.30$ & $6.33 \pm 0.8^{\star \star}$ & $2.59 \pm 0.8$ & $6.39 \pm 0.5^{\star \star}$ \\
\hline CD4-CD8-TCR $\alpha \beta^{-}$ & $2.11 \pm 0.30$ & $5.29 \pm 0.3^{\star \star}$ & $2.10 \pm 0.5$ & $4.09 \pm 1.3^{*}$ \\
\hline CD4-CD8-TCR $\alpha \beta^{\text {low }}$ & $0.14 \pm 0.01$ & $0.47 \pm 0.06^{\star *}$ & $0.16 \pm 0.04$ & $1.63 \pm 0.4^{\star *}$ \\
\hline CD4-CD8-TCR $\alpha \beta^{\text {hi }}$ & $0.40 \pm 0.02$ & $0.57 \pm 0.05$ & $0.33 \pm 0.02$ & $0.66 \pm 0.04^{\star *}$ \\
\hline $\mathrm{CD}^{+}{ }^{+\mathrm{CD}^{+}}{ }^{+}$ & $82.74 \pm 4.60$ & $70.38 \pm 3.80^{*}$ & $83.32 \pm 5.01$ & $70.54 \pm 3.6^{*}$ \\
\hline $\mathrm{CD} 4{ }^{+} \mathrm{CD} 8+\mathrm{TCR} \alpha \beta^{-}$ & $39.90 \pm 3.05$ & $46.33 \pm 2.30^{*}$ & $39.88 \pm 3.1$ & $28.15 \pm 2.1^{*}$ \\
\hline $\mathrm{CD} 4+\mathrm{CD} 8+\mathrm{TCR} \alpha \beta^{\text {low }}$ & $40.08 \pm 2.87$ & $22.56 \pm 4.30^{* *}$ & $40.09 \pm 2.52$ & $39.77 \pm 3.6$ \\
\hline $\mathrm{CD} 4+\mathrm{CD} 8+\mathrm{TCR} \alpha \beta^{\mathrm{hi}}$ & $2.76 \pm 0.54$ & $1.50 \pm 0.40^{*}$ & $3.44 \pm 0.54$ & $2.62 \pm 0.6^{*}$ \\
\hline $\mathrm{CD}^{-\mathrm{CD}} 8^{+}$ & $5.98 \pm 0.75$ & $10.18 \pm 1.10 * *$ & $5.90 \pm 0.9$ & $10.48 \pm 1.3^{\star \star}$ \\
\hline $\mathrm{CD} 4-\mathrm{CD} 8+\mathrm{TCR} \alpha \beta^{-}$ & $1.68 \pm 0.20$ & $5.26 \pm 1.40^{* *}$ & $1.70 \pm 0.3$ & $2.16 \pm 0.7$ \\
\hline CD4-CD8+TCR $\alpha \beta^{\text {low }}$ & $0.36 \pm 0.03$ & $1.65 \pm 0.21 * *$ & $0.34 \pm 0.05$ & $0.53 \pm 0.1$ \\
\hline CD4-CD8+TCR $\alpha \beta^{\text {hi }}$ & $3.94 \pm 0.70$ & $3.27 \pm 0.60$ & $3.86 \pm 1.15$ & $7.79 \pm 2.6^{\star \star}$ \\
\hline CD4+CD8- & $8.63 \pm 0.60$ & $13.11 \pm 0.60^{* *}$ & $8.20 \pm 1.5$ & $12.60 \pm 1.4^{\star *}$ \\
\hline $\mathrm{CD} 4+\mathrm{CD} 8-\mathrm{TCR} \alpha \beta^{-}$ & $0.30 \pm 0.02$ & $2.12 \pm 0.50^{\star *}$ & $0.28 \pm 0.03$ & $0.34 \pm 0.1$ \\
\hline CD4+CD8-TCR $\alpha \beta^{\text {low }}$ & $0.46 \pm 0.07$ & $1.81 \pm 0.25^{\star *}$ & $0.49 \pm 0.1$ & $0.54 \pm 0.04$ \\
\hline CD4+CD8-TCR $\alpha \beta^{\text {hi }}$ & $7.87 \pm 0.83$ & $9.18 \pm 1.20$ & $7.43 \pm 1.4$ & $11.73 \pm 2.7^{\star}$ \\
\hline
\end{tabular}

Values represent mean \pm S.D. $n=10 * * p<0.01 ;{ }^{*} p<0.05$ 
In peripubertal rats $\mathrm{SRIH}-14$ significantly decreased the percentage of $\mathrm{TCR} \alpha \beta^{\text {low/hi }}$ cells within DP thymocytes, but increased the percentage of DPTCR $\alpha \beta^{-}$cells. SRIH-14 in young adults decreased the relative proportion of DP TCR $\alpha \beta^{-/ h i}$ expressing cells. In parallel, the percentage of DP TCR $\alpha \beta^{\text {low }}$ expressing cells remains unchanged compared to control values (Table 1).

$\mathrm{SRIH}-14$, in peripubertal rats, significantly increased the relative proportion of $\mathrm{TCR} \alpha \beta^{-/ \text {low }}$ expressing cells within SP $\mathrm{CD} 8^{+}$thymocytes subpopulation, while decreased the percentage of SP CD8 ${ }^{+} \mathrm{TCR} \alpha \beta^{\text {hi }}$ mature cells, but the difference was not statistically significant in comparison to control values (Table 1). In young adult rats SRIH-14 significantly increased the percentage of SP CD8 ${ }^{+} \mathrm{TCR} \alpha \beta^{\text {hi }}$ cells compared to control. However, the percentages of thymocytes in the SP $\mathrm{CD}^{+} \mathrm{TCR} \alpha \beta^{-/ \text {low }}$ thymocytes subsets was not significantly changed in comparison to corresponding control values, although there was a small percentage increase of these cell subsets.

On the other hand, in peripubertal rats $\mathrm{SRIH}-14$ did not change significantly the percentage of SP CD4 ${ }^{+} \mathrm{TCR} \alpha \beta^{\text {hi }}$ cells, while the percentage of SP $C D 4^{+} \mathrm{TCR} \alpha \beta^{- \text {/low }}$ cells was significantly increased, in comparison with corresponding control values. However, the percentage of TCR $\alpha \beta^{\text {hi }}$ cells, within $\mathrm{SP} \mathrm{CD4}{ }^{+}$thymocytes subpopulation, was also increased in the young adult rats treated with $\mathrm{SRIH}-14$, while the remaining two subsets (SP CD4 ${ }^{+} \mathrm{TCR} \alpha \beta^{-/ l o w}$ ) were not significantly changed (Table 1).

\section{DISCUSSION}

Our results clearly showed that SRIH-14 induced a decrease of thymic weight and cellularity i.e. thymic atrophy in both age groups, but these changes had a significantly higher degree in peripubertal rats compared to young adults. In addition, somatostatin-14 in peripubertal rats increased the number of immature thymocytes as a result of changes in the thymocytes transition from the DN to DP stage, while in young adults it modulates transition of DP cells into mature SP cells.

Reduction of thymic weight and cellularity induced by SRIH-14, directly over sstr expressed in the thymus (Ferone et al., 2002; 2004; Petrovic-Djergovic et al., 2007), and/or indirectly by inhibition of GH secretion (Milosevic et al., 1996), is in the line with the data obtained in the Ames mice, deficient in $\mathrm{GH}$ and PRL secretion (Duqesnoy, 1972). These observations imply the involvement of pituitary hormones in the process of thymic atrophy, also called thymic involution (Taub and Longo, 2005). Likewise, the elevated absolute and relative thymic weight in the Ames mice, hypophysectomized rats and old mice treated with PRL, GH and IGF-I (Smith, 1930; Murphy et al., 1992; Montecino-Rodriguezet et al., 1998; Dorshkind and Horseman, 2000) indicate the association between thymic atrophy and decline in hormone levels.

Thymic involution commences at the time of puberty as the level of sex steroid hormones increases and the production of growth hormone $(\mathrm{GH})$ and insulin-like growth factor-I (IGF-I) decreases (Utsuyama and Hirokaw, 1989; 
Domínguez-Gerpe and Rey-Méndez, 2003; Taub and Longo, 2005). Thymic involution is a slow physiological process that can be accelerated by some pathological or experimental conditions (Báez-Saldaña and Ortega, 2004). Thus, our results (i.e. reduction of relative thymic weight and cellularity) indicate that application of SRIH-14 in peripubertal rats accelerates the reduction in thymus size. In contrast, in young adults this neuropeptide has inhibiting effects not only on the thymus, but also on the whole body. The diminished size of multiple tissues such as muscle and bone, as a consequence of reduced circulating GH and IGF-1 levels during ageing, supports our finding (Rudman et al., 1990).

Our results also suggest that the decreased numerical density of thymocytes in deep cortex and diminished thymocytes number in the thymic cortex and medulla (quantitatively more in the cortex), contributes to the reduction of total thymocytes count in both experimental groups. Literature data imply that this decrease may happen due to reduced entry of the thymocytes precursors into the thymus (Savino and Dardenne, 2000; Savino et al., 2002), reduced proliferation rates and massive cell death of thymocytes in the areas of the cortex (Steinmann, 1986; Sharma et al., 1996; Ferone et al., 2004). Increased apoptosis of thymocytes in SRIH-14 treated animals, induced over its receptors expressed on immature thymocytes (Ferone et al., 2002; 2004), probably is the one of the factors which contributes to the reduction of thymocytes numerical density in the thymic cortex. Bearing in mind that the loss of thymocytes is among the first alterations which occur in the thymus during physiological involution (Steinman, 1986 ) the results obtained in our study suggest that SRIH-14 may contribute to the mentioned physiological phenomenon.

In addition, SRIH-14 has opposite effects on the numerical density of thymocytes within the subcapsular region in peripubertal and young adult rats. In peripubertal rats the mentioned neuropeptide increased the numerical density of thymocytes within the subcapsular region as a consequence of accumulation of

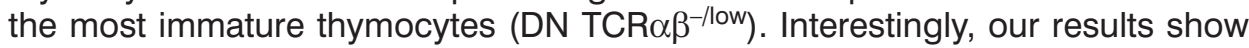
that the least mature thymocyte subset contains a minor, but significantly increased population of immature SP TCR $\alpha \beta^{-/ l o w}$ cells, which have intermediate characteristics between the CD4-CD8- cells and CD4 ${ }^{+} \mathrm{CD} 8{ }^{+}$cells (Takeuchi et al., 1993). The expression of sst3 receptor mRNA on the intermedial/mature $\mathrm{CD}^{+}$ thymocytes indicates that these cells, at least, partially contribute to SRIH mediated apoptosis (Ferone et al., 2002, 2004; Sharma et al., 1996). On the other hand, the tenfold increased percentage of DN TCR $\alpha \beta^{\text {low }}$ thymocytes undergoing apoptosis (Kersh and Hedrick, 1995) might be the reason for the decrease of thymocytes numerical density in the subcapsular cortex of young adults. Different changes in the numerical density of thymocytes within the subcapsular region in peripubertal and young adult rats might be due to the distinct distribution of sst receptors in thymocytes subsets and a reduction of sstr number during postnatal life (Ferone et al., 2000).

As a consequence of the early T-cell development block, the thymus contains atypically arranged cortical TECs, and lacks an organized medulla (Hollander et al., 1995). Taking into account that the three-dimensional organization and maintenance of the thymic cortical microenvironment is 
dependent upon signals from differentiating thymocytes (Mohtashami and Zúñiga-Pflücker, 2006), the reduced number of cortical thymocytes in both treated groups could cause the reduction in the thymic cortex volume, as a consequence of the loss of the fine stromal cells network. On the other hand, the mature T cells are involved in maintenance of the correct medullar microenvironment (Shores et al., 1994), and the reduction of the thymic medulla volume in peripubertal rats may be associated with the decrease of SP CD8 ${ }^{+} T C R \alpha \beta^{\text {hi }}$ expressing cells. Finally, in young adult animals, the absence of the changes in thymic medulla volume can be related with rise of SP TCR $\alpha \beta^{\text {hi }}$ thymocytes number.

Inhibition of thymocytes maturation at the stage of DN to DP transition and its impaired progression to the DP TCR $\alpha \beta^{\text {low }}$ stage, may be related to deprivation of hormones under SRIH influence and/or locally produced SRIH, which acts directly on very early stages of T-cells differentiation, via receptors on immature thymocytes (Ferone et al., 2002; 2004; Petrovic-Djergovic et al., 2007). Interestingly, SRIH-14 increased the percentage of immature TCR $\alpha \beta^{-/ 10 w}$ cells within both SP subpopulations, but quantitatively more in the $\mathrm{CD} 8^{+} \mathrm{TCR} \alpha \beta^{- \text {-low }}$ subset. These cells have an extremely limited lifespan despite a high proliferative rate as their progression to DP cells is very quick (Paterson and Williams, 1987). The proportional increase in DP TCR $\alpha \beta^{-}$and decrease in DP TCR $\alpha \beta^{\text {low }}$ expressing cells, observed in peripubertal treated rats, could be attributed in the augmented apoptosis of thymocytes and/or an accelerated transition of thymocytes from the DP TCR $\alpha \beta^{\text {low }}$ to DP TCR $\alpha \beta^{\text {hi }}$ stage. However, decrease of DP TCR $\alpha \beta^{\text {hi }}$ cells, which have passed a positive selection (Starr et al., 2003), indicate that SRIH-14 in peripubertal rats may be involved in the backlash positive selection.

On the other hand, in the young adult rats, increase of DN TCR $\alpha \beta^{-/ / \text {low }}$ cells and decrease of DP TCR $\alpha \beta^{-}$subset, direct precursor of DP TCR $\alpha \beta^{\text {low }}$ cells, indicates that SRIH-14 alters DN to DP transition and induces the loss of the cells with unsuccessfully rearrangement of $\beta$ chain by apoptosis (Starr et al., 2003). Somatostatin increases a minor subset of DN TCR $\alpha \beta^{\text {hi }}$ expressing cells, also. These cells represent distinct lineage cells, in adult mice, that do not follow the conventional process of selection (Budd and Mixter, 1995). In co-culture with naïve T cells and antigens, these cells express immunoregulatory activity (Wang et al., 2002). The presence of DN T regulatory cells in the lymph nodes and spleen of thymectomized mice reconstituted with $\mathrm{T}$ cell-depleted bone marrow cells suggest that these regulatory cells may preferentially develop outside the thymus (Ford et al., 2006). Changes in the proportion of DP TCR $\alpha \beta^{\text {hi }}$ and both SP TCR $\alpha \beta^{\text {hi }}$ thymocytes suggest that SRIH-14 accelerates positive selection and maturation of selected thymocytes preferentially towards SP CD8 ${ }^{+} T C R \alpha \beta^{\text {hi }}$ cells.

\section{CONCLUSIONS}

In conclusion, the accumulation of immature cells and decrease of the percentage of cells that have to pass through positive selection, observed in the peripubertal rats, as well as an increase the percentage of DNTCR $\alpha \beta^{\text {hi }}$ cells and modulation of maturation of selected thymocytes, preferentially towards SPCD8 
cells, found in the young adult rats, suggest that $\mathrm{SRIH}-14$ has different effects on thymocytes maturation depending on age. In addition, the decrease of the thymic relative weight measured in peripubertal rats indicates that $\mathrm{SRIH}-14$, although is not a critical factor for thymic involution, contributes its atrophy.

\section{ACKNOWLEDGEMENTS:}

This work is supported by a grants from the Ministry of Science of Serbia, projects No. 145049 and 145064.

\section{ABBREVIATIONS:}

DN, double negative; DP, double positive; SP, single positive; TCR, T cell receptor; SRIH, somatotropin release-inhibiting hormone; GH, growth hormone.

Address for correspondence:

PhD Mileva Mićić

Institute for Medical Research

University of Belgrade

Dr Subotića 4

PO Box 102

11129 Belgrade, Serbia

E-mail: evica@imi.bg.ac.rs

\section{REFERENCES}

1. Anderson G, Lane PJ, Jenkinson EJ, 2007, Generating intrathymic microenvironments to establish T-cell tolerance, Nat Rev Immunol, 7, 12, 954-63.

2. Anderson G, Owen JJ, Moore NC, Jenkinson EJ, 1994, Thymic epithelial cells provide unique signals for positive selection of $\mathrm{CD} 4^{+} \mathrm{CD} 8^{+}$thymocytes in vitro, $J$ Exp Med, 179, 6, 2027-31.

3. Báez-Saldaña A, Ortega $E, 2004$, Biotin deficiency blocks thymocyte maturation, accelerates thymus involution, and decreases nose-rump length in mice, $J$ Nutr, 134, 8, 1970-77.

4. Bhatena SJ, Louie J, Schechter GP, Redman R S, Wahl L, Recant L, 1981, Identification of human mononuclear leucocytes bearing receptors for somatostatin and glucagons, Diabetes, 30, 2 127-31.

5. Brazeau P, Vale W, Burgus R, Ling N, Butcher M, Rivier J et al., 1973, Hypothalamic polypeptide that inhibits the secretion of immunoreactive growth hormone, Science, 179, 77-9.

6. Budd R, Mixter $P, 1995$, The origin of CD4-CD8-TCR $\alpha \beta+$ thymocytes: a model based on T ell receptor avidity, Immunol Today, 16, 9, 428-31.

7. Domínguez-Gerpe L, Rey-Méndez M, 2003, Evolution of the thymus size in response to physiological and random events throughout life, Microsc Res Tech, 62, 6, 464-76.

8. Dorshkind K, Horseman ND, 2000, The roles of prolactin, growth hormone, insulin-like growth factor-l, and thyroid hormones in lymphocyte development and function: insights from genetic models of hormone and hormone receptor deficiency, Endocr Rev, 21, 3, 292-12.

9. Duquesnoy RJ, 1972, Immunodeficiency of the thymus-dependent system of the Ames dwarf mouse, J Immunol, 108, 6, 1578-90.

10. Elenkov IJ, Wilder RI, Chrousos GP, Vizi ES, 2000, The Symphatetic nerve - an integrative interface between two supersystems: the brain and the immune system, Pharmacol Rev, 52, 4, 595-638.

11. Ferone D, Pivonello R, Van Hagen PM, Dalm VA, Lichtenauer-Kaligis EG, Waaijers M et al., 2002, Quantitative and functional expression of somatostatin receptor subtypes in human thymocytes, Am J Physiol Endocrinol Metab, 283, 5, E1056-66.

12. Ferone D, Pivonello R, Van Hagen PM, Waaijers M, Zuijderwijk J, Colao A et al., 2000, Age-related decrease of somatostatin receptor number in the normal human thymus, $A m$ J Physiol Endocrinol Metab, 279, 4, E791-8. 
13. Ferone D, van Hagen PM, Semino C, Dalm VA, Barreca A, Colao A et al., 2004, Somatostatin receptor distribution and function in immune system, Dig Liver Dis, 36 (Suppl 1), S68-77.

14. Ferone D, van Hagen PM, van Koetsveld PM, Zuijderwijk J, Mooy DM, Lichtenauer-Kaligis EG et al., 1999 , In vitro characterization of somatostatin receptors in the human thymus and effects of somatostatin and octreotide on cultured thymic epithelial cells, Endocrinology, 140, 1, 373-80.

15. Ford SM, Zhang Z, Chen W, Zhang L, 2006, Double negative T regulatory cells develop outside the thymus and do not mature from CD8+ T cell precursors, J Immunol, 177, 5, 2803-9.

16. Gray DH, Ueno T, Chidgey AP, Malin M, Goldberg GL, Takahama $Y$ et al., 2005, Controlling the thymic microenvironment, Curr Opin Immunol, 17, 2, 137-43.

17. Hollander GA, Wang B, Nichogiannopoulou A, Platenburg PP, van Ewijk W, Burakoff SJ et al., 1995, Developmental control point in induction of thymic cortex regulated by a subpopulation of prothymocytes, Nature, 373, 350-53.

18. Kersh GJ, Hedrick SM, 1995, Role of TCR specificity in CD4 versus CD8 lineage commitment, $J$ Immunol, 154, 3, 1057-68.

19. Krantic S, 2000 Peptides as regulators of the immune system: emphasis on somatostatin, Peptides, 21, 12, 1941-64.

20. Lamberts SWJ, van den Beld AW, van der Lely AJ, 1997, The endocrinology of aging, Science, 278, 419-24.

21. Leposavić G, Mićić M, Todorović V, 1992, Rat thymus cells bind antibodies against insulin, glucagons and somatostatin, J Neuroimmunol, 46 (suppl), 62.

22. Maggiano N, Piantelli M, Ricci R, Larocca LM, Capelli A, Raneletti FO, 1994, Detection of growth hormone-producing cells in human thymus by immunocytochemistry and nonradioactive in situ hybridization, J Histochem Cytochem, 42, 10, 1349-54.

23. Martens H, Malgrange B, Robert F, Charlet C, De Groote D, Heymann D et al., 1996, Cytokine production by human thymic epithelial cells: control by the immune recognition of the neurohypophysial self-antigen, Regul Pept, 67, 1, 39-45.

24. Mentlein R, Kendall MD, 2000, The brain and thymus have much in common: a functional analysis of their microenvironments, Immunol Today, 21, 3, 133-40.

25. Milosevic V, Velkovski S, Brkic B, Sekulic M, Lovren M, Starcevic V et al., 1996, Inhibitory effects of centrally administred somatostatin on the adrenal zona glomerulosa in male rats, Pharmacology, 53, 6, 369-75.

26. Min H, Montecino-Rodriguez E, Dorshkind K, 2006, Reassessing the role of growth hormone and sex steroids in thymic involution, Clin Immunol, 118, 1, 117-23.

27. Mohtashami M, Zúñiga-Pflücker JC, 2006, Cutting edge: Three-dimensional architecture of the thymus is required to maintain delta-like expression necessary for inducing $T$ cell development, J Immunol, 176, 2, 730-4.

28. Montecino-Rodriquez E, Clark R, Dorshkind K, 1998, Effects of insulin-like growth factor administration and bone marrow transplantation on thymopoiesis in aged mice, Endocrinology, 139, 10, 4120-6.

29. Murphy WJ, Durum SK, Longo DL, 1992, Human growth hormone promotes engraftment of murine or human T cells in severe combined immuno-deficient mice, Proc Natl Acad Sci USA, 89, 10, 4481-5.

30. Paterson DJ, Williams AF, 1987, An intermediate cell in thymocyte differentiation that expresses CD8 but not CD4 antigen, J Exp Med, 166, 5, 1603-8.

31. Petrović-Djergović D, Rakin AK, Kuštrimović NZ, Ristovski JS, Dimitrijević Lj A, Mićić MV, 2007, Somatostatin modulates T cells development in adult rat thymus, Reg Pep, 142, 3, 101-10.

32. Rezzani R, Bonomini F, Rodella LF, 2008, Histochemical and molecular overview of the thymus as site for T-cells development, Prog Histochem Cytochem, 43, 2, 73-120.

33. Rudman D, Axel FG, Nagraj HS, Gergans GA, Lalitha PY, Goldberg AF et al., 1990, Effects of human growth hormone in men over 60 years old, $N$ Engl J Med, 323, 1, 1-6.

34. Savino W, 2007, Neuro-endocrine control of T cell development in mammals: role of growth hormone in modulating thymocyte migration, Exp Physiol, 92, 5, 813-7. 
35. Savino W, Dardenne M, 2000, Neuro-endocrine control of thymic physiology, Endocrinol Rev, 21, 4, 412-43.

36. Savino W, Mendes-da-Cruz DA, Silva JS, Dardenne M, Cotta-de-Almeida V, 2002, Intrathymic T-cell migration: a combinatorial interplay of extracellular matrix and chemokines? Trends Immunol, 23, 6, 305-13.

37. Serri O, Brazeau P, Kachra Z, Posner B, 1992, Octreotide inhibits insulin-like growth factor-I hepatic gene expression in the hypophysectomized rat: evidence for a direct and indirect mechanism of action, Endocrinology, 130, 4, 1816-21.

38. Sharma K, Patel YC, Srikant CB, 1996, Subtype-selective induction of wild-type p53 and apoptosis, but not cell cycle arrest, by human somatostatin receptor 3, Mol Endocrinol, 10, 12, 1688-96.

39. Shores EW, van Ewijk W, Singer A, 1994, Maturation of medullary thymic epithelium requires thymocytes expressing fully assembled CD3yTCR complexes, Int Immunol, 6, 9, 1393-402.

40. Silva $A B, A w D$, Palmer $D B, 2008$, Functional analysis of neuropeptides in avian thymocyte development, Dev Comp Immunol, 32, 4, 410-20.

41. Smith $P, 1930$, The effect of hypophysectomy upon the involution of the thymus in the rat, Anat Rec, $47,1,119-43$.

42. Starr TK, Jameson SC, Hogquist KA, 2003, Positive and negative selection of T cells, Ann Rev Immunol, 21, 1, 139-76.

43. Steinmann GG, 1986, Changes in the human thymus during aging, Curr Top Pathol, 75, 43-8.

44. Takeuchi Y, Fujii Y, Okumura M, Inada K, Nakahara K, Matsuda H 1993, Characterization of CD4 ${ }^{+}$ single positive cells that lack CD3 in the human thymus, Cell Immunol, 151, 2, 481-90.

45. Taub $D D$, Longo $L D, 2005$, Insights into thymic aging and regeneration, Immunological Reviews, 205, 1, 72-93.

46. Utsuyama M, Hirokawa K, 1989, Hypertrophy of the thymus and restoration of immune functions in mice and rats by gonadectomy, Mech Aging Devel, 47, 3, 175-85.

47. Van Hagen PM, Krenning EP, Kwekkeboom EP, Reubi JC, Anker-Lugienburg PJ, Lowenberg B, 1994, Somatostatin and the immune and haematopoietic system; a review, Eur J Clin Invest, 24, 2, 919.

48. Wang $R$, Wang-Zhu Y, Grey $H$, 2002, Interactions between double positive thymocytes and high affinity ligands presented by cortical epithelial cells generates double negative thymocytes with T cell regulatory activity, PNAS, 99, 4, 2181-6.

49. Weibel ER, 1979, Stereological method. In: Practical methods for biological Morphometry, Academic Press, London, 1-415.

\title{
SOMATOSTATIN-14 IZAZIVA RAZLIČITE PROMENE U TIMUSIMA PREPUBERTALNIH I MLADIH ODRASLIH PACOVA
}

\author{
RAKIN K ANA, PETROVIĆ-ĐERGOVIĆ M DANICA, TODOROVIĆ N VERA, \\ ŽIVKOVIĆ P IRENA, ĐIKIĆ DRAGOSLAVA, MILJKOVIĆ BILJANA, JANKOVIĆ I \\ i MIĆIĆ V MILEVA
}

\section{SADRŽAJ}

Sa obzirom da literarurni podaci ukazuju da somatostatin ima uticaja na funkciju timusa, kao i da se tokom postnatalnog života menja nivo somatostatina i ekspresija njegovih receptora u timusu, cilj ovog rada je bio da se ispita da li SRIH14 davan intracerebroventrikularno u prepubertalnih i mladih odraslih pacova, do- 
vodi do različitih promena u zonama timusa i profilu timocitnih subsetova. Mužjacima pacova AO soja, starim 4 i 10 nedelja, ugrađene su kanile u treću moždanu komoru i oni su tretirani somatostatinom, ukupno tri doze, ubrizgane svakog drugog dana. U prepubertalnih pacova tretman somatostatinom dovodi do smanjenja relativne mase i zapremine timusa, kao i zapremine timusnih zona, naročito dubokog korteksa, što je bila posledica gubitka timocita apoptozom. Takođe, SRIH-14 je doveo do povećanja procenta timocita nezrelog fenotipa $\left(\mathrm{DNTCR} \alpha \beta^{- \text {/low }}, \mathrm{DPTCR} \alpha \beta^{-}\right.$, SPCD8TCR $\alpha \beta^{-/ \text {low }}$ i SPCD4TCR $\alpha \beta^{-/ \text {low }}$ ) prekusora DPTCR $\alpha \beta^{\text {low }}$ subpopulacije, smanjenja procenta DPTCR $\alpha \beta^{\text {low }}$ i DPTCR $\alpha \beta^{\text {hi }}$ subsetova, dok je relativni odnos najzrelijih CD4TCR $\alpha \beta^{\text {hi i }}$ CD8TCR $\alpha \beta^{\text {hi }}$ timocita ostao neizmenjen. $U$ mladih adulta primena somatostatina, iako dovodi do smanjena zapremine i celularosti korteksa ne dovodi do promena u relativnoj masi timusa. Procenat DPTCR $\alpha \beta^{-/ h i}$ timocita je bio smanjen, dok je procentualno učešće DNTCR $\alpha \beta^{\text {hi }}$ timocita i obe jednostruko pozitivne subpopulacije (CD4TCR $\alpha \beta^{\text {hi }}$ i CD8TCR $\alpha \beta^{\text {hi }}$, više CD8TCR $\alpha \beta^{\text {hi }}$ ) u ukupnom broju timocita bilo povećano. Navedeni rezultati ukazuju da $\mathrm{SRIH-14}$ različito utiče na morfologiju timusa i na subpopulacije timocita pacova u zavisnosti od uzrasta tretiranih životinja. 